\title{
Waldenström macroglobulinemia
}

INSERM

\section{Source}

INSERM. (1999). Orphanet: an online rare disease and orphan drug data base.

Waldenström macroglobulinemia. ORPHA:33226

Waldenström macrog lobulinemia (WM) is an indolent B-cell lymphoproliferative disorder characterized by the accumulation of monoclonal cells in the bone marrow and peripheral lymphoid tissues, and associated with the production of serum immunog lobulin M (IgM) monoclonal protein. 